\title{
Vascular Expression of Extracellular Superoxide Dismutase in Atherosclerosis
}

Tohru Fukai, ${ }^{\star \S}$ Zorina S. Galis, ${ }^{\star \S}$ Xiao Ping Meng, ${ }^{\ddagger}$ Sampath Parthasarathy, ${ }^{\star \S}$ and David G. Harrison ${ }^{\star \S}$

*Division of Cardiology, Department of Medicine, and Department of Gynecology and Obstetrics, Emory University School of Medicine; and ${ }^{\S}$ Atlanta Veterans Administration Hospital, Atlanta, Georgia 30322

\begin{abstract}
We characterized a novel form of extracellular superoxide dismutase (ecSOD) in atherosclerotic vessels. Specific activity and protein expression of ecSOD was increased two- to threefold in apo E-deficient compared with control aortas. RNase protection assays demonstrated that the expected ecSOD transcript was not increased in either apo E-deficient mice or cholesterol-fed LDL receptor-deficient mice, but that a second, lower molecular weight transcript was present and became predominant as atherosclerosis progressed. Sequence analysis revealed that this novel ecSOD has a 10-bp deletion in the $3^{\prime}$ untranslated region and an asparagine to aspartic acid mutation at amino acid 21. Studies of isolated macrophages and immunohistochemistry suggested that the truncated ecSOD transcript was expressed by lipid-laden but not control macrophages. Recombinant wild-type and novel ecSODs expressed in Sf9 cells exhibited similar SOD activities. These experiments show that ecSOD expression is increased in atherosclerotic vessels and that this is characterized by an alteration in mRNA and protein structure. Further, the source of this altered ecSOD is likely the lipid-laden macrophage. The enzymatic properties of this novel ecSOD may have important implications for the function of the lipid-laden macrophage and the atherosclerotic process. (J. Clin. Invest. 1998. 101:2101-2111.) Key words: foam cell macrophage - RNase protection assay • superoxide dismutase $\bullet$ apo $\mathrm{E} \cdot$ low density lipoprotein receptor
\end{abstract}

\section{Introduction}

It has become apparent that hypercholesterolemia and atherosclerosis are associated with increased production of reactive oxygen species in the vessel wall, both from vascular cells and macrophages that accumulate within the atherosclerotic lesion (1-3). Indeed, many of the manifestations of atherosclerosis are likely secondary to the actions of reactive oxygen species (4). These include modification of lipids (5), induction of proinflammatory genes $(6,7)$, increased cellular proliferation (8), and alterations of endothelium-dependent vasodilation (9-11). One of the major cellular defenses against the super-

Address correspondence to David G. Harrison, M.D., Division of Cardiology, Emory University School of Medicine, 1639 Pierce Drive, WMB 319, Atlanta, GA 30322. Phone: 404-727-3710; FAX: 404-7273330.

Received for publication 24 October 1997 and accepted in revised form 16 February 1998.

The Journal of Clinical Investigation

Volume 101, Number 10, May 1998, 2101-2111

http://www.jci.org oxide anion $\left(\mathrm{O}_{2}{ }^{-}\right)$and formation of peroxynitrite is the superoxide dismutases (SODs) ${ }^{1}(12,13)$. Three isozymes of SOD have been identified, including a copper/zinc-containing form $(\mathrm{Cu} / \mathrm{Zn}$ SOD) which is primarily cytosolic in location (14), a manganese form (Mn SOD) which is mitochondrial in location (15), and an extracellular isozyme (16-18). Recently, it has been shown that up to one half of the total SOD in the vessel wall is this last form, known as the extracellular (ec) SOD (19, 20). In most species, the ecSOD is a tetramer composed of two disulfide-linked dimers (21). Each subunit has a molecular mass of $\sim 34 \mathrm{kD}(16)$, and is composed of an amino-terminal signal peptide which permits secretion from the cell, an active domain which binds copper and zinc, and a carboxy-terminal region which is involved in heparin binding $(22,23)$.

There has been substantial interest in the level of expression of various antioxidant defense mechanisms, and in particular that of SOD in atherosclerotic vessels. Previous studies have reported either an increase, or no change in total SOD (9, $11,24,25)$ and the expression of the cytosolic SOD (26) in lesions. Many of these studies have used semiquantitative approaches, or have studied cholesterol-fed rabbits. In this study, we sought to determine how levels of various isozymes of SOD were affected by a model of atherosclerosis which develops lesions similar to human atherosclerosis (27-30), the apo E-deficient mouse. During this study, we discovered a novel form of ecSOD induced by atherosclerosis. The novel ecSOD increases with the progression of atherosclerosis and was present both in apo E- and LDL receptor-deficient mice. In additional experiments, we examined a potential source of the novel ecSOD and determined structural differences between it and the native mouse ecSOD.

\section{Methods}

Animals studied. apo E-deficient mice were weaned at 4 wk of age and maintained on regular chow for 2-8 mo. C57BL/6 mice were purchased from The Jackson Laboratory (Bar Harbor, ME) and maintained on regular chow for 2-8 mo. LDL receptor knockout mice were maintained on regular chow for 3 mo and then on a $1.25 \%$ cholesterol diet containing $15.75 \%$ fat, and $0.5 \%$ sodium cholate for 3 mo. Diet and water were provided ad libitum. The protocol for animal use was approved by the Emory University Committee on Institutional Animal Care and Use.

Determination of aortic SOD activity. Tissues were homogenized in $10 \mathrm{vol}$ of $50 \mathrm{mM}$ potassium phosphate ( $\mathrm{pH} 7.4$ ) containing $0.3 \mathrm{M}$ $\mathrm{KBr}$ and a cocktail of protease inhibitors $(0.5 \mathrm{mM}$ PMSF, $3 \mathrm{mM}$ diethylene-triaminepentaacetic acid, $90 \mathrm{mg} / \mathrm{liter}$ of aprotinin, $10 \mathrm{mg} / \mathrm{li}$ ter of pepstatin, $10 \mathrm{mg} /$ liter of chymostatin, and $10 \mathrm{mg} /$ liter of leupeptin). The homogenates were then sonicated and extracted at $4^{\circ} \mathrm{C}$ for $30 \mathrm{~min}$. The extracts were then centrifuged at 3,000 $\mathrm{g}$ for $15 \mathrm{~min}$.

SOD activity was assayed by monitoring the inhibition of the rate of xanthine oxidase-mediated reduction of cytochrome $c(\mathrm{pH} \mathrm{7.4),} \mathrm{as}$

1. Abbreviations used in this paper: HRP, horseradish peroxidase; ecSOD, extracellular SOD; RACE, rapid amplification of cDNA ends; SOD, superoxide dismutase; UTR, untranslated region. 
described previously (31). Cyanide $(3 \mathrm{mM})$ was used to distinguish between the cyanide-sensitive isozymes $\mathrm{Cu} / \mathrm{Zn}$ SOD and ecSOD and the cyanide-resistant Mn SOD. For specific analysis of ecSOD in vessel extracts, chromatography on Con A-Sepharose (Pharmacia Biotech, Piscataway, NJ) was used. Unlike Cu/Zn SOD and Mn SOD, the glycoprotein in ecSOD binds to the lectin concanavalin A. The procedure has been described previously (19).

Generation of an anti-ecSOD antibody, immunoblotting, and immunostaining. An oligopeptide corresponding to the peptides $28-47$ (DLA DRL DPV EKI DRL DLV EK) of murine ecSOD was used to generate a polyclonal antiserum in rabbits. The antibody was affinity purified using the immobilized peptide.

For Western blotting, protein samples were separated by $15 \%$ SDS-PAGE and transferred to nitrocellulose membranes (Amersham Corp., Arlington Heights, IL). The filter was blocked overnight with $20 \mathrm{mM}$ Tris, $\mathrm{pH} 7.6$, containing $137 \mathrm{mM} \mathrm{NaCl}, 0.1 \%$ Tween 20 (TBST) and $6 \%$ milk, and subsequently incubated in TBST containing $1 \%$ milk with a 1:80,000 dilution of a rabbit anti-ecSOD antibody for $2 \mathrm{~h}$ at room temperature. The antibodies bound to Western blots were developed with the chemiluminescent ECL detection system (Amersham Corp.) using 1:2,000 dilution of goat anti-rabbit secondary antibody conjugated to horseradish peroxidase (HRP) (Bio-Rad Laboratories, Richmond, CA) on a standard x-ray system.

Isolation of RNA and ribonuclease protection assay. To obtain a riboprobe for RNase protection assays, we amplified the ecSOD genomic DNA using PCR. The mRNA for the ecSOD is derived from one exon, and thus provided an excellent template for this purpose. Lung DNA was harvested using the TRI-reagent (Molecular Research Center, Inc., Cincinnati, OH). Because it was difficult to amplify the full-length ecSOD sequence using only primers from $5^{\prime}$ and $3^{\prime}$ ends of the molecule (F1, corresponding to intronic sequence, and $\mathrm{R} 1)$, we used internal primers $(\mathrm{F} 2, \mathrm{R} 2)$ in conjunction with external $5^{\prime}$ and $3^{\prime}$ primers (F1 and R1) to amplify the respective $5^{\prime}$ and $3^{\prime}$ halves of the full-length sequence (Table I). Splicing-by-overlap extension was then used to obtain a full-length mouse ecSOD sequence. The resultant PCR product was gel purified, digested, subcloned into the BamH1/XhoI sites of the pBluescript SK vector (Stratagene Inc., La Jolla, CA) and sequenced by the dideoxy-chain termination method using the Sequenase 2.0 kit (USB Biologicals, Cleveland, $\mathrm{OH}$ ). The sequence obtained was similar to that reported previously (32) (GenBank accession no. U38261).
To perform RNase protection assays, total RNA was extracted from aortas of C57BL/6, apo E-deficient, and LDL receptor-deficient mice as mentioned above. After linearization of the near fulllength ecSOD DNA with XhoI, labeled antisense RNA was transcribed from the T3 promoter using Maxiscript (Ambion Inc., Austin, TX) and $\left[\alpha-{ }^{32} \mathrm{P}\right]$ UTP according to the instructions of the manufacturer. The length of this riboprobe was 923 nucleotides, which protected 828 nucleotides of ecSOD transcripts (riboprobe 1; see Fig. 2). The murine glyceraldehyde-3-phosphate dehydrogenase (GAPDH) riboprobe was obtained from Ambion Inc. Newly synthesized ${ }^{32} \mathrm{P}-$ labeled GAPDH and ecSOD antisense riboprobes $\left(\sim 7 \times 10^{4} \mathrm{cpm}\right)$ were gel purified and coprecipitated with total RNA (10-20 $\mu \mathrm{g})$. The RNA pellets were dissolved in hybridization buffer (Hybspeed RPA kit; Ambion Inc.) at $100^{\circ} \mathrm{C}$, heated at $100^{\circ} \mathrm{C}$ for $3 \mathrm{~min}$, and incubated at $68^{\circ} \mathrm{C}$ overnight. The samples were then incubated with $20 \mathrm{U}$ of RNase $\mathrm{T} 1$ for $30 \mathrm{~min}$ at $37^{\circ} \mathrm{C}$, in a total volume of $110 \mu \mathrm{l}$, to digest unhybridized RNA. An RNase inactivation/precipitation mixture, supplied by the manufacturer, was added to precipitate the ${ }^{32} \mathrm{P}$-labeled RNA-RNA hybrids. Precipitates were subjected to $5 \%$ polyacrylamide/8 M urea sequencing gels. Protected fragments were quantified by scanning densitometry of autoradiographs.

In other experiments, in which we sought to map differences in sequence between ecSOD found in C57BL/6 and in apo E-deficient mice, three separate riboprobes were generated for use in RNAse protection assays. Two of these (riboprobes 2 and 3; Fig. 1) corresponded to the $5^{\prime}$ and $3^{\prime}$ portions of the full-length sequence of murine ecSOD. To produce the $5^{\prime}$ riboprobe (riboprobe 2, nucleotides -66 to +363 ), PCR primers were designed to amplify the $5^{\prime}$ half of the ecSOD sequence and $71 \mathrm{bp}$ of the pBluescript vector sequence. This allowed detection of differences between the undigested probe and the protected fragment in subsequent RNase protection assays (Fig. 1, and Table I). To obtain the $3^{\prime}$ riboprobe (riboprobe 3, nucleotides +318 to +796 ), the pBluescript plasmid containing the full length of ecSOD cDNA fragment was linearized with StuI (which cuts ecSOD at +318 ) to allow generation of an antisense RNA probe using T3 RNA polymerase (riboprobe 3; Fig. 1). A third riboprobe was created which corresponded to nucleotides +344 to +756 of the murine ecSOD (riboprobe 3; Fig. 1). In these RNase protection assays, both $0.5 \mathrm{U}$ of RNase A and $20 \mathrm{U}$ of RNase T1 were used.

Cloning and sequencing of the ecSOD form in apo E-deficient mice. Cloning of the ecSOD expressed in normal and Apo E-defi-

Table I. Primers Used for Cloning and Riboprobe Construction

\begin{tabular}{|c|c|c|c|}
\hline Primer & Position* & Sequence & Template \\
\hline F1 & -66 to -40 & 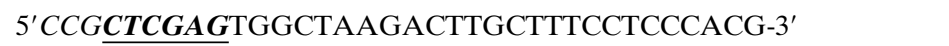 & Lung \\
\hline $\mathrm{F} 2$ & 344 to 363 & $5^{\prime}$-GCTTCCCAGCTGAGCAGAAC-3' & Lung, aorta \\
\hline $\mathrm{F} 2^{\prime}$ & 344 to 363 & 5'-GCTTCCCAGCTGAGCAGAACCCTGCAGCCCGGGGGATCCA-3' & Lung \\
\hline $\mathrm{F} 2^{\prime \prime}$ & 344 to 363 & 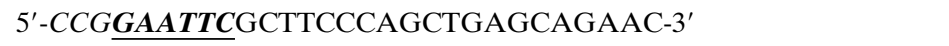 & Aorta \\
\hline F3 & 737 to 756 & 5'-GCGAGTGCAAGACCACTTAACCTGCAGCCCGGGGGATCCA-3' & Lung \\
\hline F4 & -59 to -38 & 5'-AACTTCACCAGAGGGAAAGAGC-3' & Aorta \\
\hline F5 & -29 to -9 & 5'-CGGAATTCGAGCCTGACA GGTGCAGAGAA-3' & Aorta \\
\hline F6 & 254 to 273 & 5'-TGCCACCGGATCAGCCGCAG-3' & Aorta \\
\hline $\mathrm{R} 1$ & 769 to 796 & 5'-CGGGATCC CTGGAGACATCTATGCGTGCA GCGGCG-3' & Lung \\
\hline $\mathrm{R} 2$ & 344 to 363 & 5'-GTTCTGCTCAGCTGGGAAGC-3' & Lung, aorta \\
\hline $\mathrm{R} 2^{\prime}$ & 344 to 363 & 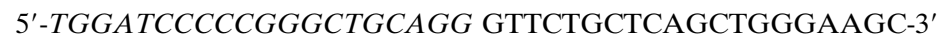 & Lung \\
\hline R3 & & 5'-AATTAACCCTCACTAAAGGG-3' & $\mathrm{T} 3$ promoter \\
\hline $\mathrm{R} 4$ & 737 to 756 & 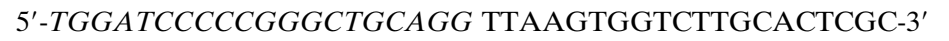 & Lung \\
\hline R5 & & 5'-GGCCACGCGTCGACTAGTACTTTTTTTTTTTTTTTTT-3' & 3'RACE \\
\hline R6 & & 5'-GGCCACGCGTCGACTAGTAC-3' & Adapter \\
\hline R7 & 824 to 843 & 5'-ACGCGTCGACGAGGCCTCTGGGGTGACTAG-3' & Aorta \\
\hline
\end{tabular}

* Numbers indicate nucleotide positions from translation start site. Italics in F2', F3, R2', and R4 show the viral sequence from pBluscript, and underlined bold italics in F1, F2", F5, R1, and R7 show the restriction site. 


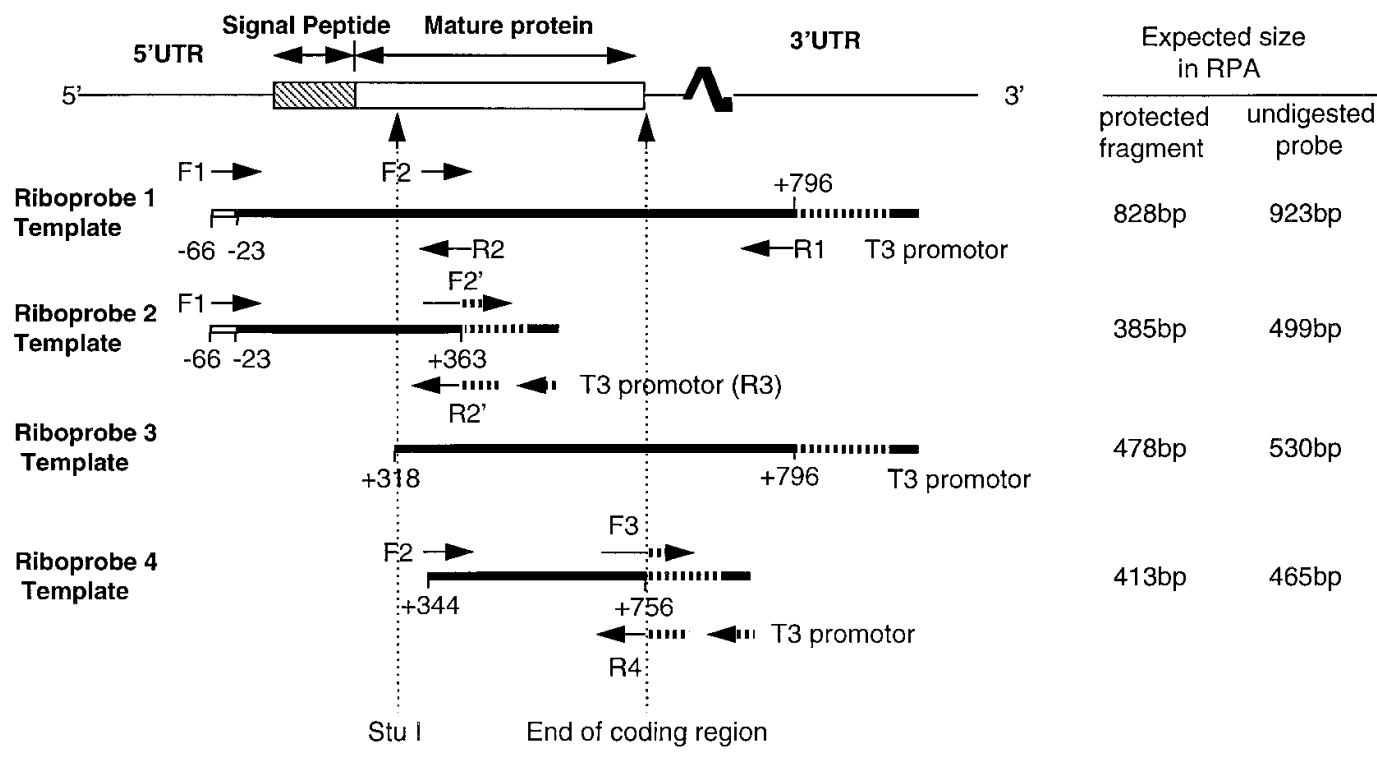

Figure 1. Structure of ecSOD protein and riboprobes used for RNase protection assays. For examination of ecSOD mRNA expression, riboprobe 1 was constructed using overlapping PCR primers (F1, F2, R1, and R2) from genomic DNA from mouse lung. Riboprobes 2, 3, and 4 were used to map differences in ecSOD mRNA between control and apo E-deficient mice. The primers used and the size of the mRNA fragment protected by each riboprobe are given. $R P A$, RNase protection assay.

cient mouse aortas was performed using a combination of $3^{\prime}$ rapid amplification of cDNA ends ( $3^{\prime}$ RACE), and PCR was performed using overlapping primers as shown in Fig. 2 and Table I. 3'RACE was performed using first-strand cDNA prepared by using an adapterlinked oligo(dT) primer (R5) (Fig. 2, and Table I). Initial PCR amplifications were carried out using primers R6 and F6 (Fig. 2, and Table I). A second PCR was performed using the reverse transcription product as a template and internal primers R6 and F2" (Fig. 2, and Table I). Primer R6 was composed of the adapter sequence in primer R5. The final 3'RACE products were gel purified, subcloned into the EcoR1/SalI site of pBluescript SK, and sequenced using the dideoxytermination method of Sanger and a commercially available kit (Sequenase; USB Biologicals). Near full-length sequences of the ecSOD expressed in normal and apo E-deficient mice were obtained using two rounds of PCR, initially with primers F4 and R7 and subsequently with primers F5 and R7. Primer R7 corresponded to a common sequence of the $3^{\prime}$ untranslated region (UTR) of the novel and wild-type ecSOD. A similar approach was used to determine the sequence of the ecSOD expressed by lipid-laden macrophages.

Isolation of macrophages from carrageenan-induced granuloma in apo E-deficient and C57BL/6 mice. To induce granuloma formation, sterile $1 \%$ carrageenan was injected subcutaneously in apo E-deficient and C57BL/6 mice. The animals were killed 3 wk later, and the macrophage-rich granulomas were harvested. To isolate macrophages, the granulomas were minced and then incubated under sterile conditions with HBSS containing type 1 collagenase, elastase, and soybean trypsin inhibitor. The resultant turbid fluid was then filtered through a sterile nylon mesh filter, and cells were collected in sterile tubes. Macrophages were then isolated by metrizamide density centrifugation as described previously (3). Aliquots of cells were resuspended in Opti-MEM (GIBCO BRL, Gaithersburg, MD) and used for Western analysis and RNase protection assays.

Histochemical studies. For studies of isolated macrophages, the presence of intracellular lipid was confirmed by staining with Nile red (Molecular Probes Inc., Eugene, OR). Cells were fixed in $4 \%$ paraformaldehyde and $0.1 \%$ Triton $\mathrm{X}-100$ and washed three times with PBS. Nile red $(5 \mu \mathrm{g} / \mathrm{ml})$ was added to the cells at room temperature for $10 \mathrm{~min}$. The cells were washed again with PBS, and the nuclei were counterstained with Hoechst and visualized with a fluorescent microscope. Expression of ecSOD was examined using immunofluorescence with the anti-ecSOD antibody (1:2,000 dilution) followed by an FITC-labeled secondary antibody (Jackson ImmunoResearch Laboratories, West Grove, PA).

For immunohistochemical studies of aortic segments, tissues were embedded in OCT (Miles Inc., Elkhart, IN) and frozen using liquid nitrogen. Cryosections were stained with either anti-ecSOD (1: $10,000)$ or an anti-mouse macrophage antibody (MOMA-2, 1:500; Serotec Ltd., Oxford, UK) followed by either HRP-conjugated goat anti-rabbit IgG (1:100; Bio-Rad Laboratories) or HRP-conjugated rabbit anti-rat antibody (1:100; Sigma Chemical Co., St. Louis, MO), respectively. Staining was developed using the LSAB kit (DAKO Corp., Carpinteria, CA).

Expression of wild-type and novel ecSOD in baculovirus/Sf9 cells. To compare SOD activity between the wild-type and novel forms of the ecSOD, the cDNAs encoding each were cloned into the EcoR1 and BamH1 sites of the vector pVL 1392. This vector with the respective inserts was used to cotransfect $\mathrm{Sf} 9$ cells with Baculogold viral DNA (PharMingen, San Diego, CA). Successful expression of the two forms of ecSOD was confirmed using Western analysis, and viral stocks from initial transfections were used to infect subsequent Sf9 cultures to amplify the amounts of recombinant protein expressed. Media from Sf9 cells were subjected to concanavalin A-Sepharose chromatography, and SOD activities were compared between the wild-type and novel forms of the enzyme as described above.

\section{Results}

SOD activity in aortas of control and apo E-deficient mice. Total SOD activity was similar in the aortas of control and apo E-deficient mice (Fig. $3 A$ ). However, when specific assays for each SOD isozyme were performed, it was found that ecSOD activity was significantly higher in the aorta from apo E-deficient than C57BL/6 mice ( $1.68 \pm 0.54$ vs. $0.74 \pm 0.25 \mathrm{U} / \mathrm{mg}$ total protein, respectively; $P<0.05)$. $\mathrm{Cu} / \mathrm{Zn} \mathrm{SOD}$ and $\mathrm{Mn}$ SOD activity were not different in aortas of these two groups (Fig. 3 B).

Protein expression of ecSOD in aortic segments. Western blots consistently revealed two bands in both control and apo E-deficient mice at the expected molecular size (Fig. $4 A$ ). The upper band seemed compatible with the previously identified type $\mathrm{C}$ ecSOD, while the lower band likely reflected immu- 


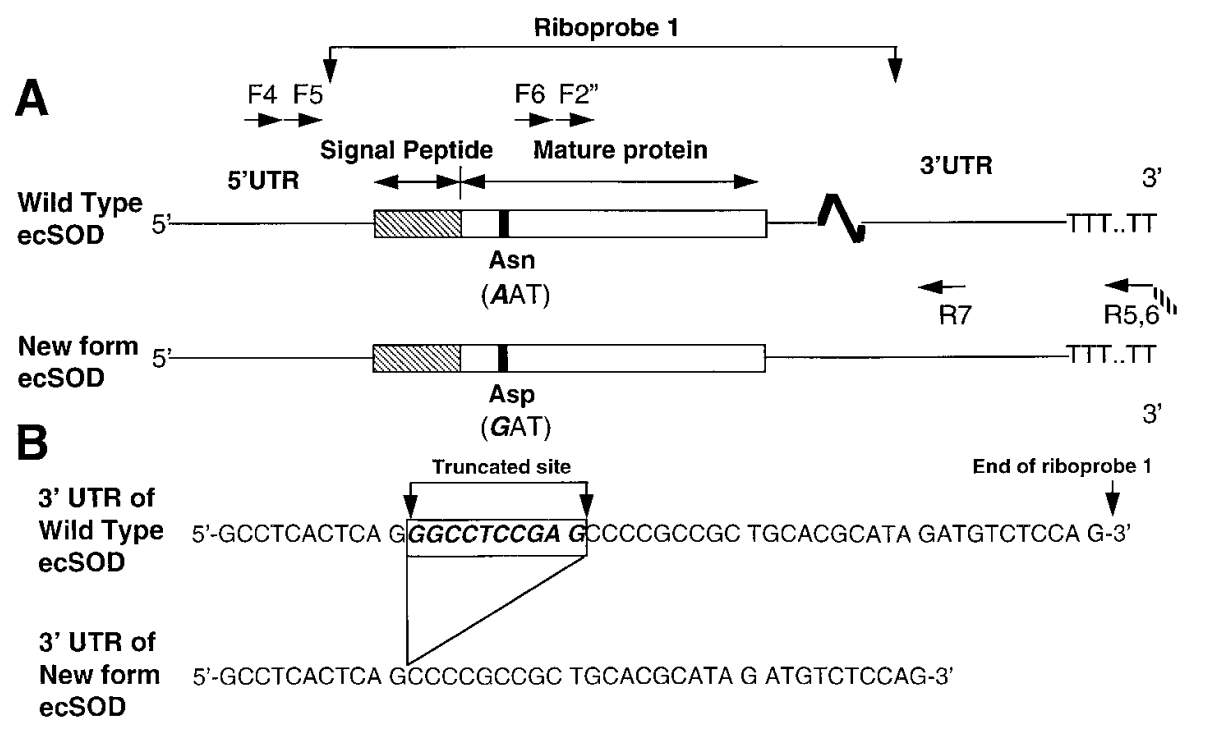

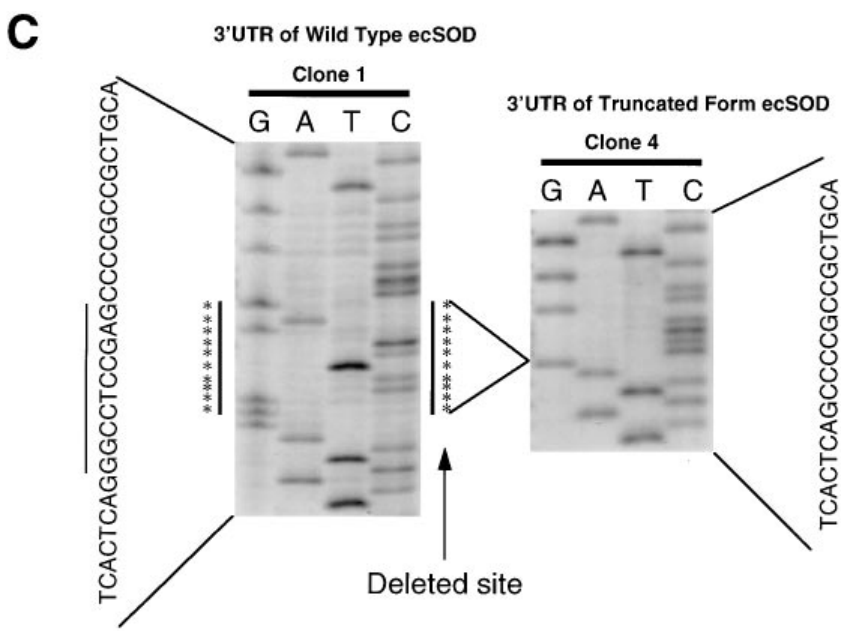

A

Total SOD

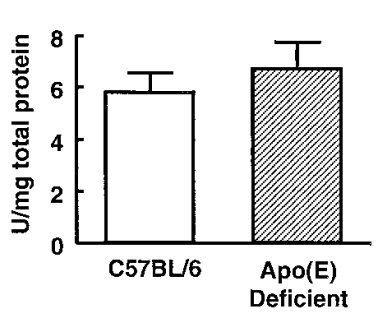

SOD Isozymes

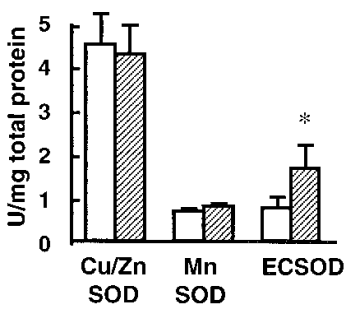

Figure 3. Total SOD activity in aortas of control (C57BL/6, white bars) and apo E-deficient (striped bars) mice $(A)$ and activities of individual SOD subtypes $(B)$. Aortas were homogenized, and total SOD activity was assayed by examining inhibition cytochrome $c$ reduction by xanthine/xanthine oxidase at $\mathrm{pH}$ 7.4. The activity of $\mathrm{Mn}$ SOD was examined by addition of $\mathrm{KCN}(3 \mathrm{mM})$. The activity of ecSOD was determined after separation with Con A-Sepharose. Aortas from eight mice were combined for each experiment $(n=3$ for each data point). The results are presented as mean $\pm S E M$, and the values are expressed as units per milligram of total protein. $* P<0.05$ vs. C57BL/6.

Figure 2. (A) Strategy used for cloning and sequencing the wild-type and truncated forms of the ecSOD from control and apo E-deficient mouse aortas. Reverse transcription of RNA was performed using primer R5, and 3'RACE was performed using primers R6 and F2". Near full-length sequences of both wild-type and truncated forms of ecSOD were obtained using primers $\mathrm{F} 4$ and R5 initially and then the nested primers F5 and R7. Also shown is the A to G substitution at nucleotide 61 in the ecSOD in apo E-deficient mice and the resultant asparagine to aspartic acid change at amino acid 21. ( $B$ and $C$ ) Comparison of sequences of the $3^{\prime} \mathrm{UTR}$ between the wild-type and truncated ecSODs.

noreactivity with the type A (carboxy-terminal region proteolyzed) subunit. The expression of these two bands was increased approximately threefold in the aortas from apo E-deficient compared with control mice by densitometry (Fig. 4 B). In addition to bands at the expected molecular weight, higher molecular weight bands were observed consistently in homogenates of aortas from apo E-deficient mice, and observed faintly in homogenates from control mice. One of these had an approximate molecular mass of $68 \mathrm{kD}$, suggesting the existence of a dimer. This $68-\mathrm{kD}$ band was inhibited when the antibody was preabsorbed with the peptide against which it was raised. A 44-kD band was observed that was not eliminated by preabsorption with the peptide, suggesting that this band was nonspecific.

Immunohistochemical staining of aortic sections demonstrated preferential expression of ecSOD in the intima of atherosclerotic lesions (Fig. $5 \mathrm{~A}$ ). These regions also stained strongly for macrophages (Fig. $5 B$ ), suggesting colocalization of macrophages with the ecSOD. Higher magnifications demonstrated positive staining in and around lipid-laden macrophages (Fig. $5 \mathrm{C}$ ). Smooth muscle cells of apo E-deficient mouse aortas and control mice demonstrated low levels of staining for ecSOD (Fig. $5 A$ and $D$ ). Control mouse aortas did not exhibit macrophage staining (Fig. $5 D$, inset). 


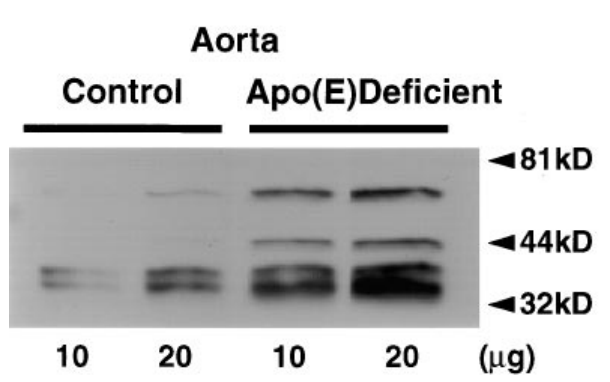

ecSOD mRNA expression in aortas of control (C57BL/6), apo E-deficient, and LDL receptor knockout mice. RNase protection assays using the full-length riboprobe (riboprobe 1) demonstrated that the expected ecSOD transcript was not increased in aortas from apo E-deficient compared with control mice, but interestingly, a second lower molecular weight transcript was identified only in atherosclerotic vessels (Fig. $6 A$ ). As the apo E-deficient mice aged, the expression of the wildtype transcript decreased, while expression of the novel, smaller molecular weight form increased (Fig. 6, $A$ and $B$ ).
Figure 4. (A) Western analysis of ecSOD protein in aortas of $\mathrm{C} 57 \mathrm{BL} / 6$ and apo E-deficient mice. 10 and $20 \mu \mathrm{g}$ of protein from tissue homogenates of aortas of both C57BL/6 and apo E-deficient mice were loaded in adjacent lanes and size separated on SDS gel. After transfer to a nitrocellulose membrane, ecSOD protein was detected by immunoblotting with affinitypurified rabbit polyclonal antibody raised against the peptides $28-47$ of the murine ecSOD. (B) Densitometric analysis of Western blots for ecSOD protein expression in control $(\bigcirc)$ and atherosclerotic $(\bullet)$ mice. Data are mean \pm SEM for $n=5$.
This finding was not restricted to only the apo E-deficient mouse model of atherosclerosis, as a similar transcript could be detected in the aortas of LDL receptor-deficient mice which also develops atherosclerosis (Fig. $6 C$ ).

Sequence of the wild-type and novel ecSOD. RNase protection assays with a $5^{\prime}$ riboprobe (riboprobe 2 ) and with a riboprobe corresponding to the coding region of ecSOD (riboprobe 4) revealed only one transcript of the expected size in the apo E-deficient and normal mouse aortas (Fig. 7, $A$ and $B)$. In contrast, when a $3^{\prime}$ riboprobe containing sequence com-
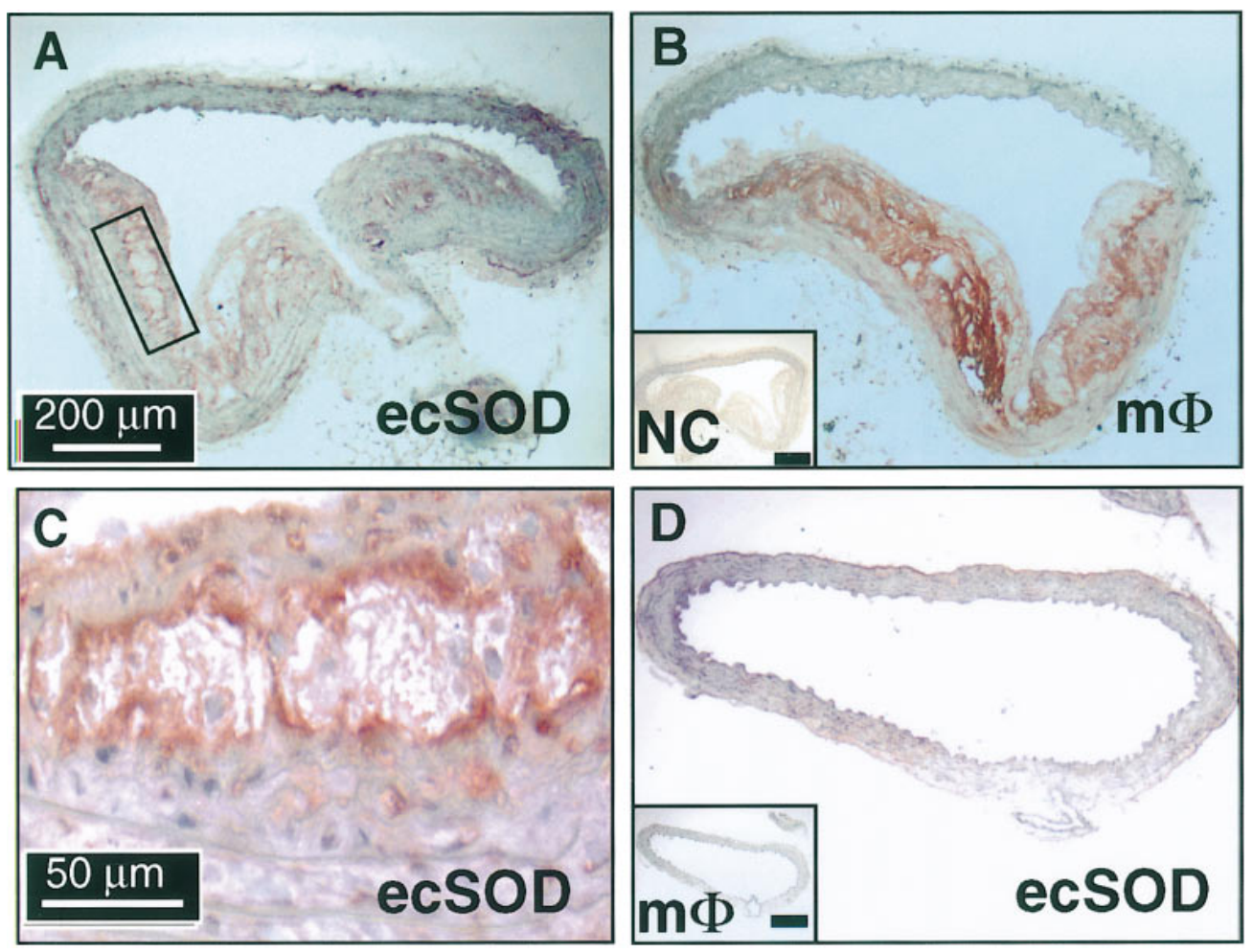

Figure 5. (A) Immunohistochemical analysis of ecSOD expression in apo E-deficient mouse aorta. Immunostaining was performed using the antiecSOD antibody $(1: 10,000)$ followed by HRP-conjugated goat anti-rabbit IgG (1:100; Bio-Rad Laboratories). Pink, Immunoreactivity with ecSOD, prominent in the intima. (B) Immunohistochemical detection of macrophages in apo E-deficient mouse aorta. MOMA-2, an antimouse macrophage antibody (Serotec Ltd.), was used as the primary antibody (1:100), and an HRP-conjugated rabbit anti-rat antibody (Sigma Chemical Co.) was used as a secondary antibody (1:100). Inset, Absence of staining when primary antibody was omitted. (C) High magnification of region within rectangle in $A$. Shown is positive staining for ecSOD surrounding lipidladen macrophages (clear region). (D) Staining for ecSOD in a control mouse aortic segment. Methods are identical to those used for A. Inset, Macrophage staining control vessels using methods identical to those in $B$. 


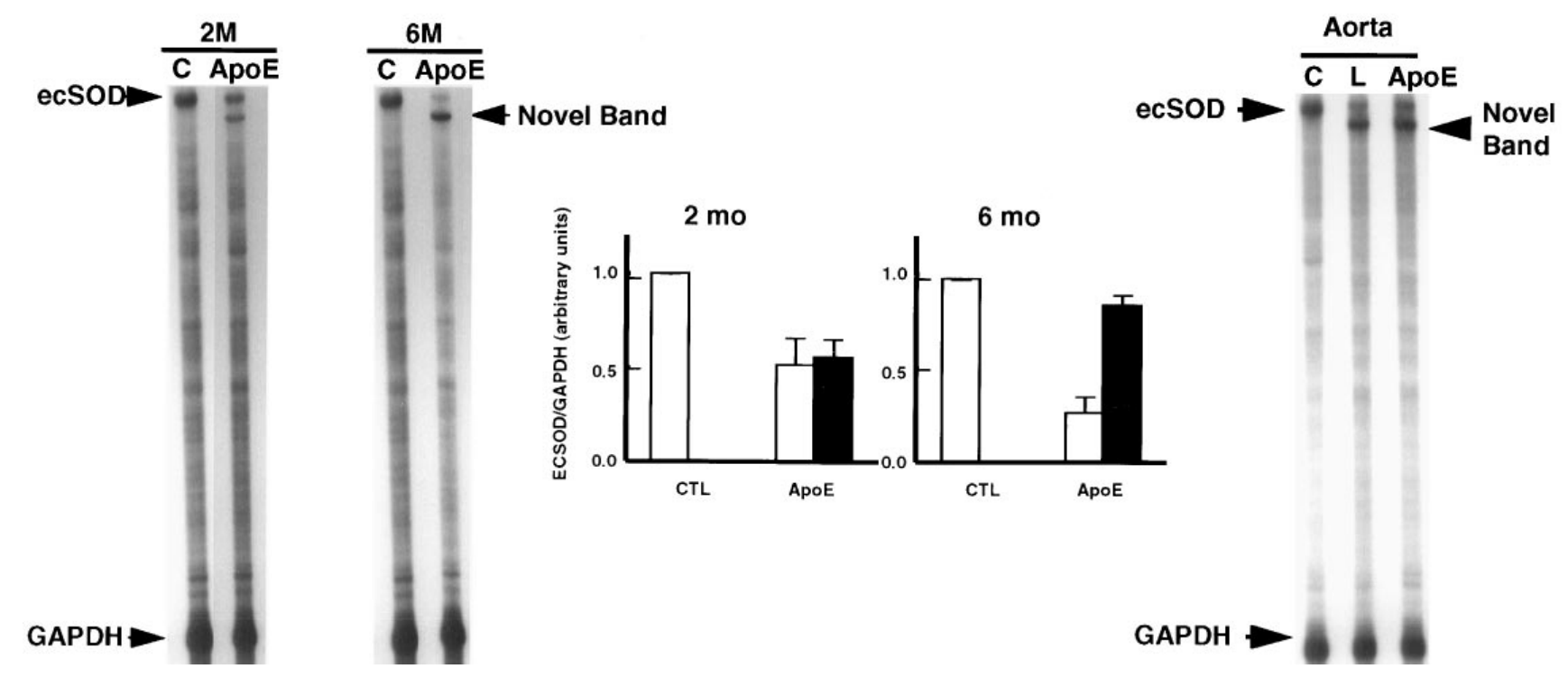

Figure 6. (A) Expression of ecSOD mRNA in aortas of control and apo E-deficient mice at 2 and 6 mo of age. For each of these experiments, the control $(C)$ mice were of the same age as the apo E-deficient mice. RNase protection assay was performed using riboprobe 1 (Fig. 1) and a riboprobe for GAPDH as an internal control for loading. $(B)$ Densitometric analysis of ecSOD mRNA in young and 6-mo-old mice for the wildtype (white bars, CTL) and truncated ecSOD mRNA (black bars, Apo E). Data are $n=4$ for the 2-mo-old mice and $n=9$ for the 6-mo-old mice. $(C)$ Comparison of ecSOD mRNA in aortas of control $(\mathrm{C} 57 \mathrm{BL} / 6, C)$, LDL receptor-deficient $(L)$, and apo E-deficient mice. LDL receptordeficient mice were fed a $1.25 \%$ cholesterol diet beginning at age 3 mo until 6 mo of age. The apo E-deficient mice were studied at 6 mo of age in this experiment.

plimentary to the $3^{\prime}$ UTR (riboprobe 3 ) was used, a truncated fragment was detected, as well as the expected size transcript (Fig. $7 \mathrm{C}$ ). The difference in size between these two transcripts was similar to that observed when the full-length riboprobe (ri-
A

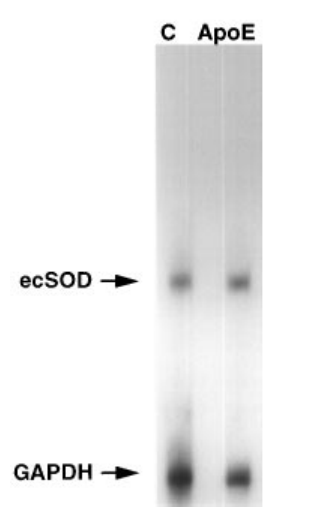

B

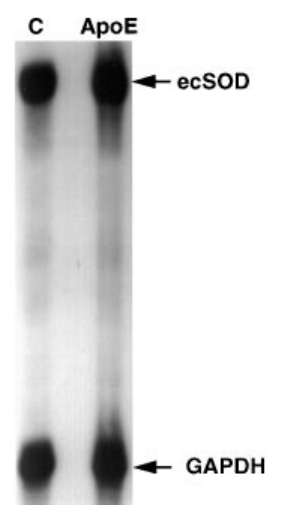

C

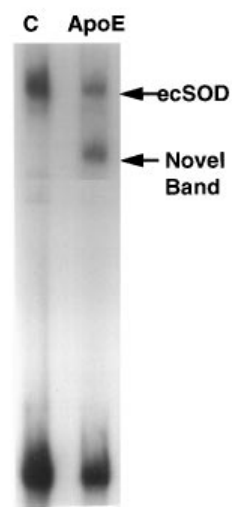

Figure 7. Determination of the truncated site of the ecSOD mRNA in apo E-deficient mice aortas. Labeled riboprobes directed against the $5^{\prime}$ half (riboprobe $2, A$ ), the $3^{\prime}$ half of the coding region (riboprobe 4 , excluding the $3^{\prime} \mathrm{UTR}, B$ ), and the $3^{\prime}$ two-thirds (riboprobe 3 , which includes the $3^{\prime} \mathrm{UTR}, C$ ). RNase protection assays were performed as described in the citation to Fig. 5. Mice were 6 mo of age at the time of study. Only riboprobe 3 detected the truncated ecSOD transcript, indicating that the site of the deleted sequence was in the 3'UTR. C, C57BL/6. boprobe 1) was used, indicating that the major alteration in sequence of the novel ecSOD present in atherosclerotic mice is in the $3^{\prime}$ portion of the mRNA. In keeping with this, $3^{\prime} \mathrm{RACE}$ revealed a deletion of 10 bases (5'GGCCTCCGAG3') in the $3^{\prime} \mathrm{UTR}$ (Fig. 2) in four of five clones selected from apo E-deficient mice. The sequences of all four of these clones were identical, while one clone contained no truncation and was identical to the wild-type ecSOD sequence. The sequences of all five clones from $\mathrm{C} 57 \mathrm{BL} / 6$ mice were identical.

Using PCR with a forward primer complementary to a sequence in the $5^{\prime}$ UTR and a reverse primer that was $3^{\prime}$ to the truncation, it was possible to amplify a near full-length sequence for both the novel and wild-type forms of ecSOD. In addition to the deletion detected using $3^{\prime}$ RACE, an A to G substitution was noted at nucleotide +61 in the ecSOD from the apo E-deficient mice. This was noted in four of five independent clones sequenced. This substitution resulted in a codon change from AAT to GAT and a consequent change in amino acid encoded of asparagine to aspartic acid.

Examination of macrophage expression of ecSOD. The above studies indicated that a novel form of ecSOD was expressed in atherosclerotic vessels, and immunohistochemical staining indicated that it colocalized with lipid-laden macrophages. Therefore, we performed studies to examine expression of ecSOD in tissue-differentiated macrophages. Macrophagerich granulomas were induced by subcutaneous carrageenan injection, and macrophages were harvested 3-4 wk later. Interestingly, macrophages from the subcutaneous granulomas of apo E-deficient mice exhibited the appearance of foam cells, as evidenced by Nile red staining (Fig. $8 A$ ), whereas macro- 

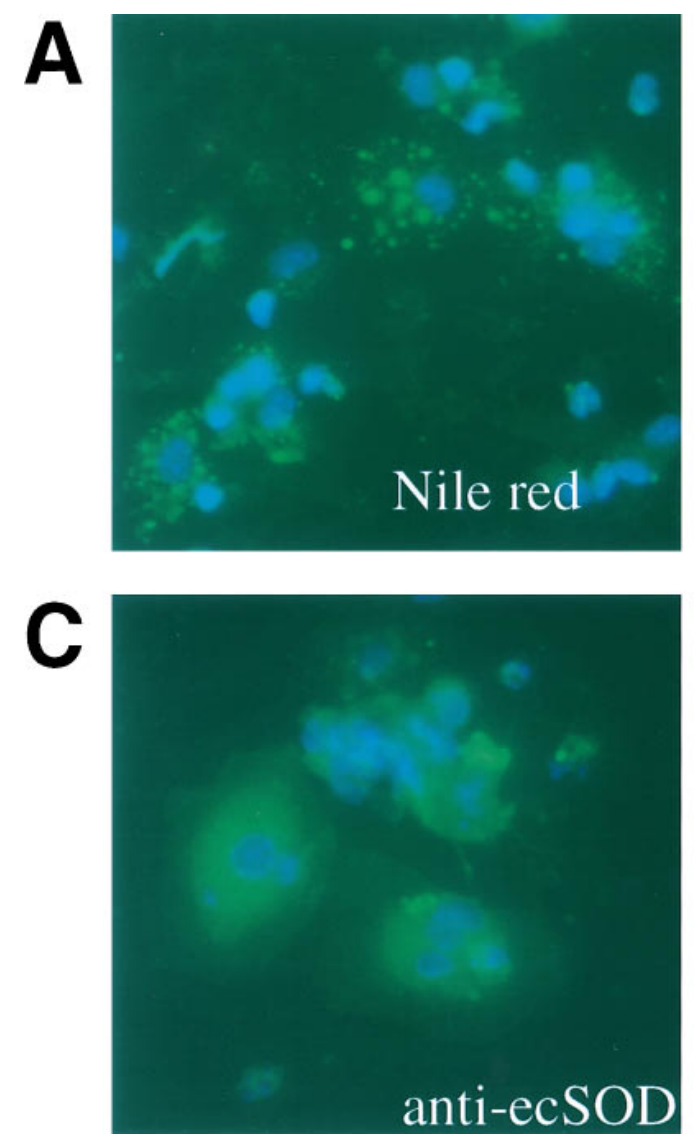
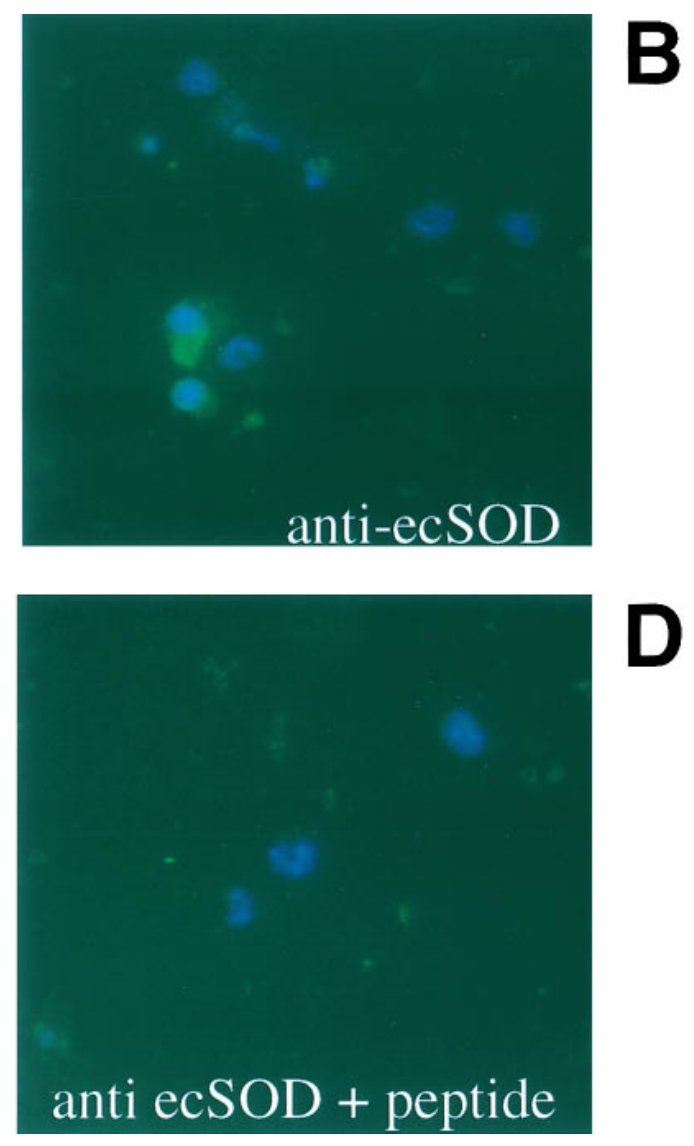

Figure 8. Detection of intracellular lipid and ecSOD in macrophages obtained from carrageenan-induced granulomas in control (C57BL/6) and apo E-deficient mice. Staining with Nile red-O demonstrated intracellular lipid droplets indicative of foam cell formation $(A)$. Immunofluorescence detection of ecSOD, using an immunopurified antibody against ecSOD in macrophages from $\mathrm{C} 57 \mathrm{BL} / 6$ mice $(B)$ and apo E-deficient mice $(C)$. Immunostaining was reduced when the antibody was preincubated with the peptide against which the antibody was raised $(D)$. phages from normal C57BL/6 mice did not. Macrophages from normal mice exhibited only faint staining for ecSOD protein (Fig. $8 \mathrm{~B}$ ), whereas macrophages from apo E-deficient mice displayed marked fluorescence staining for ecSOD (Fig. $8 C$ ). The immunofluorescence was reduced markedly when excess amounts of the polypeptide against which the ecSOD antibody was raised were added during incubation with the primary antibody (Fig. $8 \mathrm{D}$ ).

RNase protection assays of macrophages from control mice demonstrated the expected size protected band. However, in lipid-laden macrophages from apo E-deficient mice, both the expected RNA fragment and a lower molecular weight fragment were observed (Fig. $9 A$ ). The size of the lower molecular weight protected band seemed identical to that found in aortas of atherosclerotic mice (Fig. 6). The total ecSOD mRNA was increased by $\sim 1.8-2$-fold in macrophages from apo E-deficient compared with control mice (Fig. $9 B$ ). To examine the sequence of the ecSOD expressed by macrophages, total RNA from lipid-laden macrophages was subjected to reverse transcription, and the resultant DNA was used as a template for PCR as described for aortic samples in the citation to Fig. 2. The ecSOD sequence of lipid-laden macrophages was found to be identical to that of the novel ecSOD isolated from aortas of apo E-deficient mice.

In keeping with the immunohistochemical studies (Fig. 5), macrophages from normal mice exhibited minimal or no ecSOD expression by Western blotting (Fig. 9 C). In contrast, lipid-laden macrophages from apo E-deficient mice exhibited three bands of $\sim 34,40$, and $68 \mathrm{kD}$. Of these, the 34- and 68-
$\mathrm{kD}$ bands were specifically inhibited by the addition of the oligopeptide against which the ecSOD antibody was raised, whereas the $40 \mathrm{kD}$ band was not eliminated (not shown). The $34-\mathrm{kD}$ band was identical in size to that identified in aortas of both control and apo E-deficient mice (Figure $4 A$ ).

Activity of wild-type and novel ecSODs expressed as recombinant proteins in $S f 9$ cells. Western analysis of media from Sf9 cells expressing the wild-type ecSOD revealed bands of a molecular weight consistent with the monomeric form of the enzyme (Fig. $10 \mathrm{~A}$ ). Interestingly, Western analysis of media from Sf9 cells expressing the novel form of ecSOD revealed both a monomeric band and higher molecular weight form, consistent with a dimer and of similar molecular weight to that observed in aortas and lipid-laden macrophages from apo E-deficient mice (Fig. $10 \mathrm{~A}$ ). Similar quantities of ecSOD protein were expressed in the two Sf9 infectants. SOD activities in the media of Sf9 cells expressing the wild-type and novel ecSODs were similar (Fig. $10 \mathrm{~B}$ ). By contrast, media of control (noninfected) Sf9 cells did not exhibit ecSOD protein or activity (Fig. 10, $A$ and $B$ ).

\section{Discussion}

This study provides new information regarding expression and function of SODs in atherosclerosis. An important finding was that in vessels of apo E-deficient mice, ecSOD activity and protein expression are increased by two-to threefold, whereas the activities of the cytosolic $\mathrm{Cu} / \mathrm{Zn}$ SOD and Mn SOD are not changed. Surprisingly, by RNase protection assay, the ex- 


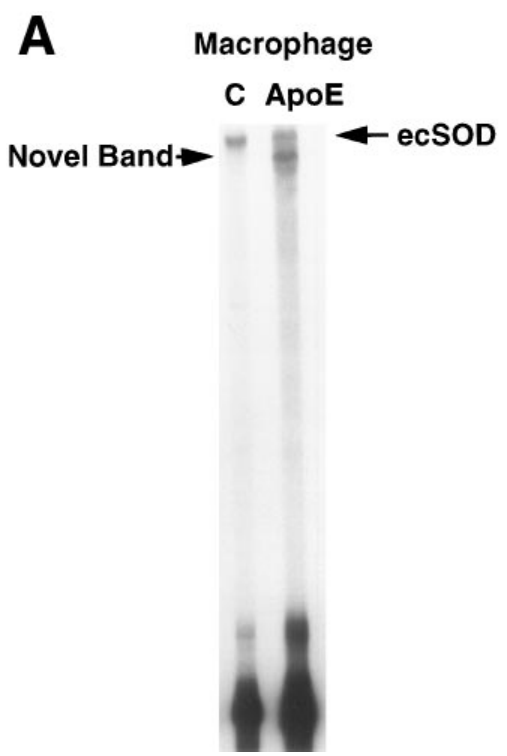

C

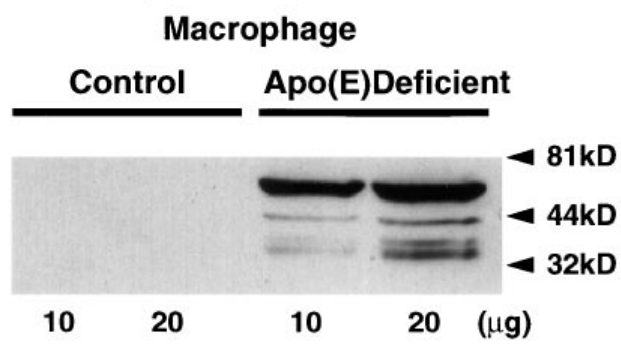

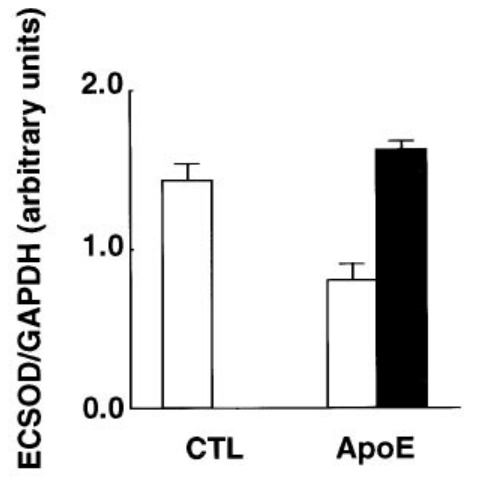

D

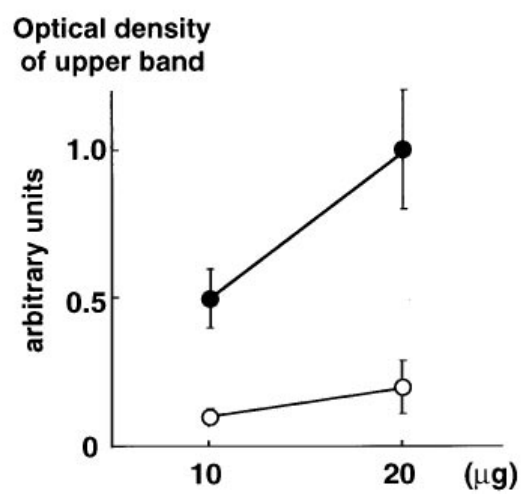

Figure 9. Extracellular SOD expression in macrophages from normal and hypercholesterolemic mice. Macrophages were obtained from carrageenan-induced granulomas as in citation to Fig. 7. (A) A representative RNase protection assay comparing ecSOD mRNA expression in macrophages from control $(\mathrm{C} 57 \mathrm{BL} / 6, C)$ and apo E-deficient mice. (B) Densitometric analysis of ecSOD mRNA normalized to GAPDH mRNA for both the expected and truncated ecSOD transcripts. Data are mean \pm SEM for three experiments. Each experiment involved pooling RNA from two mice in each group. White bars, Wildtype. Black bar, Truncated form. (C) A Western blot examining ecSOD expression in macrophages from carrageenan-induced granulomas obtained from control (C57BL/6) and apo E-deficient mice. Western analysis was performed as described in the citation to Fig. 4. (D) Densitometric analysis of Western blots of macrophages from three $\mathrm{C} 57 \mathrm{BL} / 6(\mathrm{O})$ and three apo E-deficient mice $(\bullet)$. Data are mean \pm SEM for $n=3$. pected ecSOD mRNA transcript was not increased; however, a novel shorter transcript was present in both apo E-deficient and LDL receptor-deficient mice. A 10-bp deletion within the $3^{\prime}$-UTR and a missense mutation within the coding region, resulting in an Asn to Asp conversion, characterized the novel transcript. Additional studies indicated that at least one source of this novel ecSOD was the lipid-laden macrophage. Further, the protein, when expressed in lipid-laden foam cells, seemed to migrate both as a monomer and as a dimer on SDS-reducing gel.

Previous studies have reported either an increase or no change in total SOD and the expression of the cytosolic $\mathrm{Cu} / \mathrm{Zn}$ SOD in atherosclerotic lesions (9, 11, 24-26). Many of these studies have used semiquantitative approaches or have studied cholesterol-fed rabbits, which develop predominantly a lipid-
A

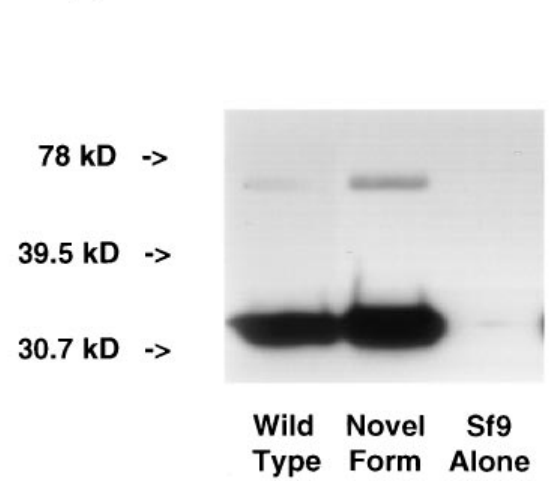

B

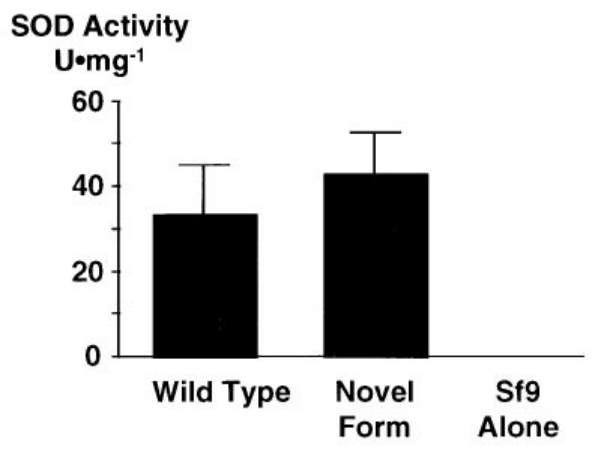

Figure 10. (A) Western analysis of wildtype and novel ecSOD expressed as recombinant proteins in $\mathrm{Sf} 9$ cells. Media from the representative Sf9 cells were used for analysis. Western analyses were performed as described in the citation to Fig. 4. (B) SOD activity of ecSOD expressed in Sf9 cells. SOD activity was performed as described in the citation to Fig. 3. Media from the respective cells were subjected to Con A-Sepharose chromotography, and the semipurified ecSODs were used for both Western analysis and SOD activity. 
rich lesion. In this study, we used a model of atherosclerosis, the apo E-deficient mouse, which has lesions similar to those observed in human atherosclerosis (27-30). In vessels from these animals, ecSOD activity and protein expression were increased by two- to threefold, whereas activity of other isozymes, such as $\mathrm{Cu} / \mathrm{Zn} \mathrm{SOD}$ and $\mathrm{Mn} \mathrm{SOD}$, was not changed. One might question the relevance of the increase in ecSOD expression when total SOD activity remained unchanged. However, it is apparent that the location of the ecSOD is quite different from that of the intracellular isozymes of SOD, and an increase in ecSOD expression may have important implications for modulation of the redox state in the interstitial space in atherosclerotic vessels. In addition, our finding that foam cell macrophage expression of ecSOD is increased may have important implications for the production of oxygen radicals by these cells. Since the lipid-laden macrophage is an important component of human atheroma, it is conceivable that ecSOD expression by these cells may be important in the human disease.

RNase protection assays demonstrated that the expected ecSOD transcript was not increased in aortas from apo E-deficient compared with control mice. However, a truncated ecSOD transcript not present in vessels of control mice was observed consistently in atherosclerotic vessels. To examine the effect of the extent of atherosclerosis on expression of ecSOD, we studied apo E-deficient mice at 2 and 6 mo of age. These two ages correspond to an early stage of atherosclerosis and a stage when atherosclerosis is more advanced $(29,30)$. Interestingly, the total ecSOD mRNA expression was not altered significantly from 2 to 6 mo of age; however, the distribution between the expected and truncated ecSOD transcripts changed with time. Thus, at 6 mo of age, there was a relative decrease in expression of the expected size transcript and an increase in the shorter transcript (Fig. 6, $A$ and $B$ ).

To characterize the two ecSOD transcripts, these were isolated, cloned, and sequenced. Two separate differences between the truncated and wild-type ecSOD transcript were found. The 3'UTR of the truncated ecSOD contains a 10-bp deletion, and one missense mutation is present near the $5^{\prime}$ portion of the coding region, resulting in an aspartic acid rather than an asparagine in amino acid position 21 . The explanation for these alterations in sequence remains unknown. Of note, both these sequences have been reported previously. Marklund and co-workers have reported a sequence isolated from mouse liver that was identical to that found by us in vessels of apo E-deficient mice (32). In contrast, Crapo and co-workers reported a sequence (GenBank accession no. U38261) identical to that observed by us in control mice and the genomic sequence we isolated initially from mouse lung. It is possible that the one base alteration within the coding region is due to RNA editing or oxidative modification of DNA in atherosclerotic vessels (33-36). A similar A to G change due to type IV RNA editing (34) has been reported for the mouse brain $N$-methyl$\mathrm{D}$-aspartate receptor (35) and for the serotonin $2 \mathrm{C}$ receptor pre-mRNA (36). The 10-bp deletion in the coding region is more likely due to alternative splicing. It is extremely unlikely that these differences in sequence are the direct consequence of a genetic alteration related to the apo E deletion, as a completely unrelated mouse model of atherosclerosis, the LDL receptor-deficient mouse, exhibited an identical pattern of ecSOD mRNA expression. Likewise, as noted above, the level of expression of the lower molecular weight transcript increased as the atherosclerosis progressed, suggesting that this was a consequence of atherosclerosis rather than an intrinsic genetic difference caused by the apo E gene disruption.

Because the lower molecular weight transcript of ecSOD increased as atherosclerosis progressed, we hypothesized that it could be a product of macrophages, which accumulate in vessels during the atherosclerotic process. This hypothesis was strengthened by immunohistochemical staining, which showed that the enzyme colocalized with lipid-laden macrophages in atherosclerotic lesions (Fig. 5). Therefore, we performed additional studies to examine expression of ecSOD in non-lipidand lipid-laden macrophages. To study macrophages, we induced granulomas in normal and apo E-deficient mice using subcutaneous carrageenan injections. Macrophages from subcutaneous granulomas from apo E-deficient mice exhibited the appearance of lipid-laden foam cells, as evidenced by Nile red staining (Fig. $8 \mathrm{~A}$ ), whereas macrophages from normal C57BL/6 mice did not. These findings agree with reports by Schwartz et al. (37), who showed that granuloma macrophages from normocholesterolemic rabbits were consistently nonlipid-laden, while those from hypercholesterolemic rabbits were lipid-laden. This approach allowed us to obtain sufficient material to examine expression of ecSOD in macrophages in the two groups of mice using RNase protection assay and Western analysis. RNase protection assays demonstrated that the truncated ecSOD transcript is expressed in lipid-laden but not normal macrophages. Western analyses and immunohistochemical studies showed only minimal expression of ecSOD in non-lipid-laden macrophages from control mice. In contrast, lipid-laden macrophages expressed large amounts of ecSOD. Of note, most of the protein expressed by the macrophage appeared to migrate at a molecular weight of approximately twice that of the protein major band detected in the aorta, suggesting the formation of a dimer resistant to reducing conditions. Finally, the sequence of the lipid-laden macrophage ecSOD cDNA was identical to that of the novel form of ecSOD cloned from the aortas of apo E-deficient mice.

The above findings suggest that ecSOD expression in macrophages is stimulated as a result of or during lipid ingestion and transformation to the lipid-laden foam cell. The finding that the foam cell ecSOD seems to migrate preferentially as a dimer may be due to one of at least two mechanisms. First, it is possible that in the lipid-laden foam cell, posttranslational modifications of the protein occur which result in a more stable dimer formation. Second, it is conceivable that the Asp to Asn mutation in some way changed the affinity of the monomeric forms of the protein such that they are more resistant to SDS denaturation. Interestingly, when the two proteins were expressed in Sf9 cells, where they are likely exposed to similar degrees of oxidative stress, the novel form seemed to migrate as a dimer as well as a monomer (Fig. $10 \mathrm{~A}$ ). This finding would favor the latter explanation. It is important to note that this putative dimer formation was observed consistently in lipid-laden macrophages, variably detected in homogenates of vessels from apo E-deficient mice, but only faintly observed in vessels from normal mice (Fig. 4).

Related to this issue, it is of note that the total ecSOD mRNA expression was similar in vessels from control and apo E-deficient mice, whereas ecSOD protein was increased threefold by Western analysis. Similarly, ecSOD mRNA was increased only modestly (1.8-fold) in macrophages from apo E-deficient mice, whereas protein expression by Western 
analysis was increased substantially. If one examines results shown in Fig. 9, it is apparent that there is a substantial discrepancy between the level of ecSOD protein expression and the increase in mRNA. The mRNA for ecSOD is increased only minimally $(60 \%)$, whereas the protein expression is increased approximately fivefold in lipid-laden compared with non-lipid-laden macrophages. One explanation for this finding is that the translational efficiency of the ecSOD mRNA is increased in vessels (and in particular in macrophages) of apo E-deficient compared with control mice. Alternatively, the ecSOD protein half-life is increased in the vessels and macrophages of apo E-deficient mice. It is conceivable that the modification resulting in the above noted dimer formation also modified the decay rate, allowing accumulation of greater amounts of ecSOD in the atherosclerotic vessels. The concept that ecSOD protein level accumulates as a result of foam cell formation seems to represent a novel mechanism for regulation of protein expression.

Increased ecSOD expression in atherosclerotic vessels and in particular by foam cells may have several important implications. An obvious explanation for this finding is that the expression of ecSOD is increased in response to the oxidative environment of the macrophage and atherosclerotic vessel. This would represent a compensatory adaptive function. It is possible that it serves to scavenge superoxide produced by the activated macrophage. If this were the case, then the principal reactive oxygen species released by these cells would likely not be superoxide, but hydrogen peroxide. This could have important implications regarding the distribution of macrophagederived reactive oxygen species. Since hydrogen peroxide is more stable than superoxide and is uncharged, it is more likely to enter adjacent cells. Further, the potential redox reactions of superoxide and hydrogen peroxide are quite different. Superoxide is more capable of acting as a reducing agent, whereas hydrogen peroxide and its Fenton product hydroxyl radical are more likely to act as oxidizing agents. In addition, SODs have been shown to catalyze the nitration of tyrosines by peroxynitrite, which is produced by activated macrophages $(38,39)$. It has been reported that atherosclerotic lesions possess increased peroxidase activity (40), although the precise enzyme involved in this activity has not been identified. Finally, SODs can have peroxidative properties (41-44), in which hydrogen peroxide is used as a source of electrons and are transferred to target molecules. In this fashion, increased levels of ecSOD in the atherosclerotic vessels could participate in propagation of oxidation reactions. Such a phenomenon might contribute to an increase in fatty streak formation reported recently in fat-fed mice overexpressing $\mathrm{Cu} / \mathrm{Zn}$ SOD (45).

\section{Acknowledgments}

We particularly acknowledge Dr. Jie Du and Dr. Masuko Ushio-Fukai for their helpful discussions, and Jana Burchfield for expert technical assistance.

This work was supported by National Institutes of Health grant RO-1 HL-39006, Vascular Biology Program Project grant HL-48667, and a Veterans Affairs Merit grant.

\section{References}

1. Ohara, Y., T.E. Peterson, and D.G. Harrison. 1993. Hypercholesterolemia increases endothelial superoxide anion production. J. Clin. Invest. 91:
2546-2551.

2. Mügge, A., R.P. Brandes, R.H. Boger, A. Dwenger, S. Bode-Boger, S Kienke, J.C. Frolich, and P.R. Lichtlen. 1994. Vascular release of superoxide radicals is enhanced in hypercholesterolemic rabbits. J. Cardiovasc. Pharmacol. 24:994-998.

3. Rajagopalan, S., X.P. Meng, S. Ramasamy, D.G. Harrison, and Z.S. Galis. 1996. Reactive oxygen species produced by macrophage-derived foam cells regulate the activity of vascular matrix metalloproteinases in vitro. Implications for atherosclerotic plaque stability. J. Clin. Invest. 98:2572-2579.

4. Alexander, R.W. 1995. Theodore Cooper Memorial Lecture. Hypertension and the pathogenesis of atherosclerosis. Oxidative stress and the mediation of arterial inflammatory response: a new perspective. Hypertension (Dallas). 25:155-161.

5. Steinberg, D., S. Parthasarathy, T.E. Carew, J.C. Khoo, and J.L. Witztum. 1989. Beyond cholesterol: modification of low-density lipoproteins that increase its atherogenecity. N. Engl. J. Med. 320:915-924.

6. Satriano, J., M. Shuldiner, K. Hora, Y. Xing, Z. Shan, and D. Schlondorff 1993. Oxygen radicals as second messengers for expression of the monocyte chemoattractant protein, JE/MCP-1, and the monocyte colony-stimulating factor, CSF-1, in response to tumor necrosis factor- $\alpha$ and immunoglobin G. Evidence for involvement of reduced nicotinamide adenine dinucleotide phosphate (NADPH)-dependent oxidase. J. Clin. Invest. 92:1564-1571.

7. Marui, N., M.K. Offermann, R. Swerlick, C. Kunsch, C.A. Rosen, M. Ahmad, R.W. Alexander, and R.M. Medford. 1993. Vascular cell adhesion molecule-1 (VCAM-1) gene transcription and expression are regulated through an antioxidant-sensitive mechanism in human vascular endothelial cells. J. Clin. Invest. 92:1866-1874.

8. Gong, K.W., G.Y. Zhu, L.H. Wang, and C.S. Tang. 1996. Effect of active oxygen species on intimal proliferation in rat aorta after arterial injury. J. Vasc. Res. 33:42-46.

9. Mügge, A., J.H. Elwell, T.E. Peterson, T.G. Hofmeyer, D.D. Heistad, and D.G. Harrison. 1991. Chronic treatment with polyethylene glycolated superoxide dismutase partially restores endothelium-dependent vascular relaxations in cholesterol-fed rabbits. Circ. Res. 69:1293-1300.

10. Ohara, Y., T.E. Peterson, H.S. Sayegh, R.R. Subramanian, J.N. Wilcox, and D.G. Harrison. 1995. Dietary correction of hypercholesterolemia in the rabbit normalizes endothelial superoxide anion production. Circulation. 92: 898-903.

11. White, C.R., T.A. Brock, L.Y. Chang, J.D. Crapo, P. Briscoe, D. Ku, W.A. Bradley, S.H. Gianturco, J. Gore, and B.A. Freeman. 1994. Superoxide and peroxynitrite in atherosclerosis. Proc. Natl. Acad. Sci. USA. 91:1044-1048.

12. Beyer, W., J. Imlay, and I. Fridovich. 1991. Superoxide dismutases. Prog. Nucleic Acid Res. Mol. Biol. 40:221-253.

13. Fridovich, I. 1997. Superoxide anion radical $\left(\mathrm{O}_{2}-\right.$.), superoxide dismutases, and related matters. J. Biol. Chem. 272:18515-18517.

14. Crapo, J.D., T. Oury, C. Rabouille, J. Slot, and L.Y. Chang. 1992. Copper, zinc superoxide dismutase is primarily a cytosolic protein in human cells. Proc. Natl. Acad. Sci. USA. 89:10405-10409.

15. Weisiger, R.A., and I. Fridovich. 1973. Mitochondrial superoxide simutase. Site of synthesis and intramitochondrial localization. J. Biol. Chem. 248: 4793-4796.

16. Marklund, S.L. 1982. Human copper-containing superoxide dismutase of high molecular weight. Proc. Natl. Acad. Sci. USA. 79:7634-7638.

17. Marklund, S.L. 1984. Extracellular superoxide dismutase in human tissues and human cell lines. J. Clin. Invest. 74:1398-1403.

18. Marklund, S.L. 1984. Extracellular superoxide dismutase and other superoxide dismutase isoenzymes in tissues from nine mammalian species. Biochem. J. 222:649-655.

19. Strålin, P., K. Karlsson, B.O. Johansson, and S.L. Marklund. 1995. The interstitium of the human arterial wall contains very large amounts of extracellular superoxide dismuase. Arterioscler. Thromb. Vasc. Biol. 15:2032-2036.

20. Oury, T.D., B.J. Day, and J.D. Crapo. 1996. Extracellular superoxide dismutase in vessels and airways of humans and baboons. Free Radical Biol. Med. 20:957-965.

21. Oury, T.D., J.D. Crapo, Z. Valnickova, and J.J. Enghild. 1996. Human extracellular superoxide dismutase is a tetramer composed of two disulphidelinked dimers: a simplified, high-yield purification of extracellular superoxide dismutase. Biochem. J. 317:51-57.

22. Hjalmarsson, K., S.L. Marklund, A. Engstrom, and T. Edlund. 1987. Isolation and sequence of complementary DNA encoding human extracellular superoxide dismutase. Proc. Natl. Acad. Sci. USA. 84:6340-6344.

23. Folz, R.J., and J.D. Crapo. 1994. Extracellular superoxide dismutase (SOD3): tissue-specific expression, genomic characterization, and computerassisted sequence analysis of the human EC SOD gene. Genomics. 22:162-171.

24. Henriksson, P., K. Bergstrom, and O. Edhag. 1985. Experimental atherosclerosis and a possible generation of free radicals. Thromb. Res. 38:195-198.

25. Del Boccio, G., D. Lapenna, E. Porreca, A. Pennelli, F. Savini, P. Feliciani, G. Ricci, and F. Cuccurullo. 1990. Aortic antioxidant defense mechanisms: time-related changes in cholesterol-fed rabbits. Atherosclerosis. 81:127-135.

26. Sharma, R.C., D.W. Crawford, D.M. Kramsch, A. Sevanian, and Q. Jiao. 1992. Immunolocalization of native antioxidant scavenger enzymes in early hypertensive and atherosclerotic arteries. Role of oxygen free radicals. 
Arterioscler. Thromb. 12:403-415.

27. Zhang, S.H., R.L. Reddick, J.A. Piedrahita, and N. Maeda. 1992. Spontaneous hypercholesterolemia and arterial lesions in mice lacking apolipoprotein E. Science. 258:468-471.

28. Plump, A.S., J.D. Smith, T. Hayek, K. Aalto-Setala, A. Walsh, J.G. Verstuyft, E.M. Rubin, and J.L. Breslow. 1992. Severe hypercholesterolemia and atherosclerosis in apolipoprotein E-deficient mice created by homologous recombination in ES cells. Cell. 71:343-353.

29. Nakashima, Y., A.S. Plump, E.W. Raines, J.L. Breslow, and R. Ross. 1994. ApoE-deficient mice develop lesions of all phases of atherosclerosis throughout the arterial tree. Arterioscler. Thromb. 14:133-140.

30. Reddick, R.L., S.H. Zhang, and N. Maeda. 1994. Atherosclerosis in mice lacking apo E. Evaluation of lesional development and progression. Arterioscler. Thromb. 14:141-147.

31. Inoue, N., S. Ramasamy, T. Fukai, R.M. Nerem, and D.G. Harrison. 1996. Shear stress modulates expression of $\mathrm{Cu} / \mathrm{Zn}$ superoxide dismutase in human aortic endothelial cells. Circ. Res. 79:32-37.

32. Carlsson, L.M., J. Jonsson, T. Edlund, and S.L. Marklund. 1995. Mice lacking extracellular superoxide dismutase are more sensitive to hyperoxia. Proc. Natl. Acad. Sci. USA. 92:6264-6268.

33. Tamir, S., S. Burney, and S.R. Tannenbaum. 1996. DNA damage by nitric oxide. Chem. Res. Toxicol. 9:821-827.

34. Chan, L. 1993. RNA editing: exploring one mode with apolipoprotein B mRNA. Bioessays. 15:33-41.

35. Sommer, B., M. Kohler, R. Sprengel, and P.H. Seeburg. 1991. RNA editing in brain controls a determinant of ion flow in glutamate-gated channels. Cell. 67:11-19.

36. Burns, C.M., H. Chu, S.M. Rueter, L.K. Hutchinson, H. Canton, E. Sanders-Bush, and R.B. Emeson. 1997. Regulation of serotonin-2C receptor G-protein coupling by RNA editing. Nature. 387:303-308.
37. Schwartz, C.J., J.J. Ghidoni, J.L. Kelley, E.A. Sprague, A.J. Valente, and C.A. Suenram. 1985. Evolution of foam cells in subcutaneous rabbit carrageenan granulomas. I. Light-microscopic and ultrastructural study. Am. J. Pathol. 118:134-150.

38. Beckman, J.S., H. Ischiropoulos, L. Zhu, M. van der Woerd, C. Smith, J. Chen, J. Harrison, J.C. Martin, and M. Tsai. 1992. Kinetics of superoxide dismutase- and iron-catalyzed nitration of phenolics by peroxynitrite. Arch. Biochem. Biophys. 298:438-445.

39. Ischiropoulos, H., L. Zhu, J. Chen, M. Tsai, J.C. Martin, C.D. Smith, and J.S. Beckman. 1992. Peroxynitrite-mediated tyrosine nitration catalyzed by superoxide dismutase. Arch. Biochem. Biophys. 298:431-437.

40. Beckmann, J.S., Y.Z. Ye, P.G. Anderson, J. Chen, M.A. Accavitti, M.M. Tarpey, and C.R. White. 1994. Extensive nitration of protein tyrosines in human atherosclerosis detected by immunohistochemistry. Biol. Chem. HoppeSeyler. 375:81-88.

41. Hodgson, E.K., and I. Fridovich. 1975. The interaction of bovine erythrocyte superoxide dismutase with hydrogen peroxide: inactivation of the en zyme. Biochemistry. 14:5294-5299.

42. Hodgson, E.K., and I. Fridovich. 1975. The interaction of bovine erythrocyte superoxide dismutase with hydrogen peroxide: chemiluminescence and peroxidation. Biochemistry. 14:5299-5303.

43. Yim, M.B., P.B. Chock, and E.R. Stadtman. 1990. Copper, zinc superoxide dismutase catalyzes hydroxyl radical production from hydrogen peroxide. Proc. Natl. Acad. Sci. USA. 87:5006-5010.

44. Yim, M.B., P.B. Chock, and E.R. Stadtman. 1993. Enzyme function of copper, zinc superoxide dismutase as a free radical generator. J. Biol. Chem. 268:4099-4105.

45. Tribble, D., E. Gong, C. Leeuwenburgh, J. Heinecke, E. Carlson, J. Verstuyft, and C. Epstein. 1997. Fatty streak formation in fat-fed mice expressing human copper-zinc superoxide dismutase. Circ. Res. 17:1734-1740. 